\title{
Effect of Aeration Modes and COD/N Ratios on Organic Matter and Nitrogen Removal in Horizontal Subsurface Flow Constructed Wetland Mesocosms
}

\author{
Xin Chen ${ }^{1,2}$, Hui Zhu ${ }^{1, *}$, Yingying $X u^{3}$, Brian Shutes ${ }^{4}$, Baixing Yan ${ }^{1}$ and Qingwei Zhou ${ }^{5}$ \\ 1 Key Laboratory of Wetland Ecology and Environment, Northeast Institute of Geography and Agroecology, \\ Chinese Academy of Sciences, Changchun 130012, China; chenxin173@mails.ucas.ac.cn (X.C.); \\ yanbx@neigae.ac.cn (B.Y.) \\ 2 College of Resources and Environment, University of Chinese Academy of Sciences, Beijing 100049, China \\ 3 Key Laboratory of Songliao Aquatic Environment, Ministry of Education, School of Municipal and \\ Environmental Engineering, Jilin Jianzhu University, Xincheng Street, District 5088, \\ Changchun 130118, China; xuyingying.1019@aliyun.com \\ 4 Urban Pollution Research Centre, Middlesex University, Hendon, London NW4 4BT, UK; \\ B.Shutes@mdx.ac.uk \\ 5 Institute of Environmental Materials and Applications, College of Materials and Environmental Engineering, \\ Hangzhou Dianzi University, Zhejiang 310018, China; zhouqw@hdu.edu.cn \\ * Correspondence: zhuhui@iga.ac.cn; Tel.: +86-431-8554-2214
}

Received: 23 August 2018; Accepted: 16 October 2018; Published: 27 October 2018

check for updates

\begin{abstract}
A series of mesocosm-scale horizontal subsurface flow constructed wetlands (HSSF-CWs) were established. In Experiment 1, four artificial aeration (AA) modes, including pre-aeration at $24 \mathrm{~h}$ before the input of influent water (PA), aeration at $6 \mathrm{~h}(6 \mathrm{AA})$ and $12 \mathrm{~h}(12 \mathrm{AA})$ after the input of influent water and non-aeration (NA), were tested to obtain an optimal aeration mode for chemical oxygen demand $\left(\mathrm{COD}_{\mathrm{Cr}}\right)$ and nitrogen removal. The results showed that aeration after the input of influent water could improve the removal efficiencies of $\mathrm{COD}_{\mathrm{Cr}}$ and ammonia-nitrogen $\left(\mathrm{NH}_{4}{ }^{+}-\mathrm{N}\right)$, but lead to an accumulation of nitrate-nitrogen $\left(\mathrm{NO}_{3}{ }^{-}-\mathrm{N}\right)$. The above observation demonstrated that a single aeration cannot create an ideal alternation of aerobic and anaerobic conditions for simultaneous nitrification and denitrification. Therefore, HSSF-CWs with intermittent aeration (IA), after the input of influent water and NA were established to evaluate the combined effects of IA and influent COD/N ratios on pollutant removal in Experiment 2. The HSSF-CW with IA exhibited a better performance in $\mathrm{COD}_{\mathrm{Cr}}$ and nitrogen removal compared to HSSF-CW with NA. The highest removal percentages of $\mathrm{COD}_{\mathrm{Cr}}(90.1 \%), \mathrm{NH}_{4}{ }^{+}-\mathrm{N}(99.8 \%)$ and total nitrogen $(\mathrm{TN}, 99.5 \%)$ were achieved at a COD/N ratio of 9.3 in HSSF-CW with IA.
\end{abstract}

Keywords: horizontal subsurface flow constructed wetlands; aeration mode; organic matter removal; nitrogen removal; $\mathrm{COD} / \mathrm{N}$ ratios

\section{Introduction}

Constructed wetlands (CWs) have been widely used in many countries and regions in the last few decades, owing to their advantages of high efficiency, appropriate ecological environment, low cost and aesthetic value [1-5]. Moreover, the important role of CWs as a wildlife habitat and greenspace make them an appropriate alternative to conventional wastewater treatment, mainly in isolated small communities [6]. In CWs, the interaction of substrate, plants and microorganisms leads to natural processes (i.e., physical, chemical and biological) that are used to remove contaminants from wastewater $[7,8]$. As far as is known, the removal of organic matter and nitrogen mainly rely on 
biodegradation and the rate of biodegradation depends on dissolved oxygen (DO) concentration [9]. It was reported that a DO concentration below $0.50 \mathrm{mg} / \mathrm{L}$ is essential for denitrification and nitrification occurs when the DO concentration is above $1.50 \mathrm{mg} / \mathrm{L}$ [10]. Liu et al. [11] also reported that DO was one of the main factors affecting pollutant removal in CWs. To overcome the lack of oxygen in CWs, artificial aeration (AA) can be employed. Recently, several investigations were carried out to study the impact of aeration on organic matter and nitrogen removal in CWs. For example, high removal efficiencies of organic matter $\left(19.3 \mathrm{mg} / \mathrm{m}^{2}\right.$.day), ammonia-nitrogen $\left(\mathrm{NH}_{4}{ }^{+}-\mathrm{N}\right)\left(3.5 \mathrm{mg} / \mathrm{m}^{2} \cdot \mathrm{day}\right)$ and total nitrogen $(\mathrm{TN})\left(3.3 \mathrm{mg} / \mathrm{m}^{2}\right.$. day) were obtained simultaneously in an intermittent aerated subsurface flow constructed wetland [12]. Zapater-Pereyra et al. [13] observed an increase in the removal of organic matter (81-89\%) in an aerated horizontal subsurface flow constructed wetland (HSSF-CW). Zhang et al. [14] found that the performance of aerated and planted HSSF-CWs in organic matter and nitrogen removal were better than non-aerated HSSF-CWs. However, there is very limited information available regarding the pollutant removal performance in CWs with different aeration modes (e.g., aeration before input, aeration after input, etc.).

Influent $\mathrm{COD} / \mathrm{N}$ ratios can significantly affect the microbial degradation of chemical oxygen demand (COD), as well as the nitrification and denitrification functions of microorganisms [15-18]. A few previous studies have investigated the effect of COD/N ratios on the removal of COD and nitrogen in CWs. For example, Zhu et al. [18] found that the removal rate of TN increased with increasing $\mathrm{C} / \mathrm{N}$ ratios and achieved the greatest value at a $\mathrm{C} / \mathrm{N}$ ratio of 5 . Ding et al. [19] showed that $\mathrm{TN}$ removal rate increased when COD/N ratios increased from 0 to 9 in HSSF-CWs. The maximal nitrogen removal efficiencies $\left(\mathrm{NH}_{4}{ }^{+}-\mathrm{N} 98 \%\right.$ and $\left.\mathrm{TN} 90 \%\right)$ were achieved at a $\mathrm{C} / \mathrm{N}$ ratio of $12: 1$ by Liang et al. [3]. These above studies show contradictory results due to different experimental conditions (e.g., the types of CWs, plant species, influent loads, temperature, etc.).

Moreover, both aeration and $\mathrm{COD} / \mathrm{N}$ ratios are important factors affecting COD and nitrogen removal in CWs and the combination of both factors could lead to complicated effectiveness in CWs. Liu et al. [20] found that the TN removal rate in vertical flow constructed wetlands (VFCWs) with intermittent aeration (IA) was approximately $0.04 \sim 0.71 \mathrm{~g} / \mathrm{m}^{2} \cdot \mathrm{d}$ greater than that in VFCWs with non-aeration (NA) when the COD/N ratios ranged from 0 to 10 . Higher removal percentages of COD (96\%), $\mathrm{NH}_{4}{ }^{+}-\mathrm{N}(99 \%)$ and TN (90\%) were obtained at an influent COD/ $\mathrm{N}$ ratio of 10 in intermittently aerated VFCWs, while the removal percentages of COD (75\%), $\mathrm{NH}_{4}{ }^{+}-\mathrm{N}(25 \%)$ and $\mathrm{TN}(26 \%)$ were obtained in non-aerated VFCWs by Fan et al. [21]. In general, the influence of COD/N ratios on the removal efficiencies of pollutants may be compensated or improved by IA in HSSF-CWs. Therefore, more detailed investigation on the combined effect of IA and COD/N ratios on the performance of HSSF-CWs is necessary.

The objectives of this study were: (1) to investigate the influence of aeration modes on organic matter and nitrogen removal in HSSF-CWs; (2) to elucidate the effect of influent COD/N ratios on organic matter and nitrogen removal in both HSSF-CWs with IA and non-aeration. The results obtained from this study will both provide reference for obtaining the optimal aeration mode and COD/N ratio for increasing the efficiency of HSSF-CWs in practical application and a comprehensive understanding of the interaction between oxygen content and organic matter degradation within HSSF-CWs.

\section{Materials and Methods}

\subsection{Experimental Setup}

Two experiments were carried out in an environment-controlled greenhouse located at the Northeast Institute of Geography and Agroecology, Chinese Academy of Sciences, Changchun, China. Four parallel mesocosm-scale HSSF-CWs were constructed for treating synthetic wastewater. The schematic diagram of the HSSF-CWs is shown in Figure 1. Each respective HSSF-CW was made from plexiglas with a length of $0.98 \mathrm{~m}$, a width of $0.56 \mathrm{~m}$ and a height of $0.5 \mathrm{~m}$. The emergent plants employed in HSSF-CWs were Canna indica with an original height of $\sim 20 \mathrm{~cm}$ and a density of 
9 plants $/ \mathrm{m}^{2}$. The same cultivar of Canna indica was applied in a previous study and the results showed that it had a greater nutrient removal performance [3]. Each HSSF-CW included an inlet area $(0.16 \mathrm{~m})$, working area $(0.66 \mathrm{~m})$ and outlet area $(0.16 \mathrm{~m})$. In the working area, a $0.4 \mathrm{~m}$ layer of gravel $(10 \pm 2 \mathrm{~mm}$ in diameter) was filled at the bottom and a $0.1 \mathrm{~m}$ layer of local black soil was placed above the gravel layer for the growth of plants. The water level was maintained at $0.05 \mathrm{~m}$ below the black soil surface, giving a total water depth of $0.45 \mathrm{~m}$. The inlet and outlet area were filled with gravel with a diameter of $15 \pm 5 \mathrm{~mm}$, accordingly ensuring a uniform inlet and outlet. The gravel was rinsed thoroughly with tap water before both formal experiments were carried out. There were three sampling points for each HSSF-CW (a distance of $10 \mathrm{~cm}$ from the bottom) along the wetland.

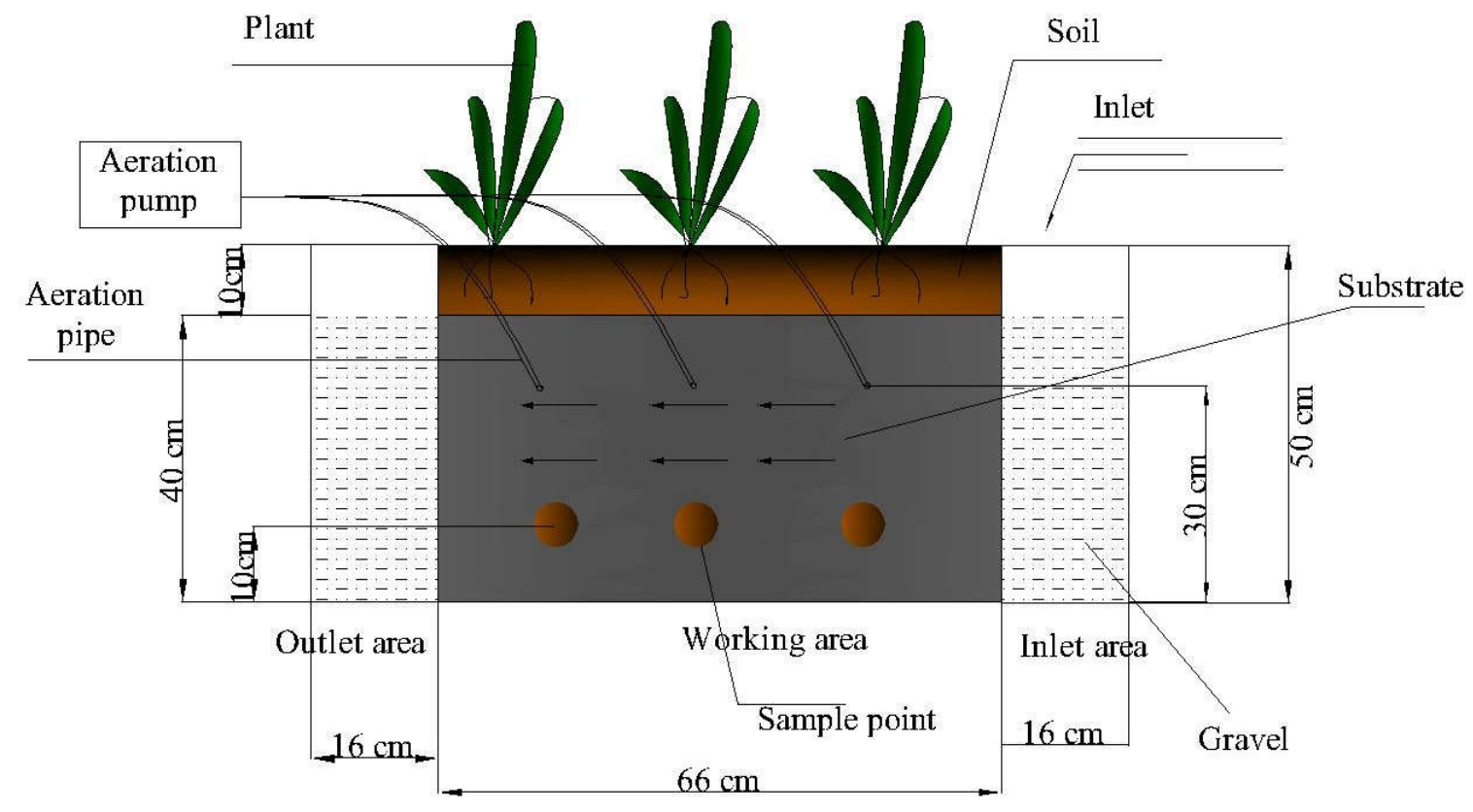

Figure 1. Experimental constructed wetland design.

In Experiment 1, four respective different aeration modes including aeration at $24 \mathrm{~h}$ before input of the influent water (PA), aeration at $6 \mathrm{~h}$ and $12 \mathrm{~h}$ after input of the influent water (refer to 6AA and 12AA, respectively) and non-aeration (NA) were tested. For HSSF-CW with PA, the aeration was constructed in a feed tank and three aeration pipes were inserted at $10 \mathrm{~cm}$ below the surface of the influent water in a feed tank. For HSSF-CWs with 6AA and 12AA, three aeration pipes were installed vertically from the surface of each HSSF-CW and the vertical distance from these pipe nozzles to the bottom of the HSSF-CWs was $0.3 \mathrm{~m}$. All the aeration pipes in HSSF-CWs with PA, 6AA and 12AA, were connected to aeration pumps and the aeration strength was $1 \mathrm{~L} \mathrm{~min}^{-1}$ for all the aerated treatments.

In Experiment 2, for the HSSF-CW with IA, the equipment was similar to HSSF-CW with 6AA in Experiment 1 and the aeration was at a frequency of $12 \mathrm{~h} /$ day after the input of influent water. HSSF-CWs without aeration (refer to NA) were set up in both Experiment 1 and Experiment 2 as controls. The environmental temperature was recorded daily during the operation of both experiments.

\subsection{Experimental Operation}

The influents were synthetically prepared in a feed tank by dissolving sodium acetate $\left(\mathrm{CH}_{3} \mathrm{COONa}\right), \mathrm{KNO}_{3}$ and $\mathrm{NH} 4 \mathrm{Cl}$ in tap water in this study. All of the chemical reagents were of analytical grade. All the treatments in both experiments were carried out for one cycle and the hydraulic retention time (HRT) was 6 days. The inflow of synthetic water to each HSSF-CW was 75 L. The experiments were carried out after Canna indica had grown in HSSF-CWs for 1 month, during which time the plants and microorganisms adapted to the wetland environment. 
In Experiment 1, the influent concentrations of $\mathrm{NH}_{4}{ }^{+}-\mathrm{N}, \mathrm{NO}_{3}{ }^{-}-\mathrm{N}$ and $\mathrm{COD}$ were $32.2 \mathrm{mg} / \mathrm{L}$, $37.2 \mathrm{mg} / \mathrm{L}$ and $222.4 \mathrm{mg} / \mathrm{L}$, respectively. In HSSF-CW with PA, the influent water was aerated at a rate of $1 \mathrm{~L} \mathrm{~min}^{-1}$ for $24 \mathrm{~h}$ in a feed tank and was then put into an HSSF-CW. In HSSF-CWs with 6AA and 12AA, the influent water was aerated at a rate of $1 \mathrm{~L} \mathrm{~min}^{-1}$ for $6 \mathrm{~h}$ and $12 \mathrm{~h}$, respectively, once it was put into the HSSF-CWs. Experiment 2 aimed to determine the effect of COD/ $\mathrm{N}$ ratios on the performance of HSSF-CWs with aeration modes of IA and NA. $\mathrm{CH}_{3} \mathrm{COONa}$ was added into the synthetic wastewater to obtain influent water with designated $\mathrm{COD} / \mathrm{N}$ ratios (i.e., 3.0, 3.9, 8.0, 9.3 and 11.0). The composition of the influent is shown in Table 1.

Table 1. The influent concentrations of pollutants under different COD/N ratios.

\begin{tabular}{cccc}
\hline $\mathbf{N H}_{\mathbf{4}}{ }^{+}-\mathbf{N}(\mathbf{m g} / \mathrm{L})$ & TN (mg/L) & COD $(\mathbf{m g} / \mathrm{L})$ & COD /N Ratios \\
\hline 59.4 & 59.7 & 180.9 & 3.0 \\
59.4 & 59.7 & 231.2 & 3.9 \\
56.4 & 60.1 & 481.3 & 8.0 \\
57.4 & 60.3 & 561.9 & 9.3 \\
59.6 & 59.7 & 659.1 & 11.0 \\
\hline
\end{tabular}

\subsection{Sampling and Analysis}

The water samples were collected daily from the three sampling points of each HSSF-CW and then mixed together to make one sample. Water samples were analyzed for dissolved oxygen (DO), oxidation-reduction potential (ORP), $\mathrm{COD}_{\mathrm{Cr}}, \mathrm{NH}_{4}{ }^{+}-\mathrm{N}, \mathrm{NO}_{3}{ }^{-}-\mathrm{N}$ and TN. DO and ORP were determined in situ by a magnetic portable multiparameter analyzer (DZB-718, INESA INSTRUMENT, Shanghai, China). $\mathrm{COD}_{\mathrm{Cr}}$ was analyzed by the potassium chromate method [22]. Concentrations of $\mathrm{NH}_{4}{ }^{+}-\mathrm{N}, \mathrm{NO}_{3}{ }^{-}-\mathrm{N}$ and TN were determined by using a full-automatic analyzer (SMART CHEM200, Italy). Data analysis and cartography were performed using Origin 9.0.

\section{Results and Discussion}

\subsection{Influence of Aeration Modes on Performance of HSSF-CWs}

\subsubsection{DO and ORP Change in HSSF-CWs with Different Aeration Modes}

DO plays an important role in regulating microbial activity in wetlands and is a crucial environmental parameter that controls nitrification and organic matter biodegradation processes [19]. The distribution of DO and ORP in the four HSSF-CWs with different aeration modes are presented in Figure 2. As is shown in Figure 2a, the influent DO concentrations were all approximately $6.28 \mathrm{mg} / \mathrm{L}$ in HSSF-CWs with 6AA, 12AA and NA treatments, while DO concentration in HSSF-CW with PA treatment was $8.30 \mathrm{mg} / \mathrm{L}$ due to pre-aeration at $24 \mathrm{~h}$ before input. For HSSF-CW with NA treatment, a fast depletion of DO mainly occurred during the first $6 \mathrm{~h}$, causing anoxic/anaerobic conditions with $\mathrm{DO} \leq 1 \mathrm{mg} / \mathrm{L}$. In HSSF-CW with PA treatment, although the initial DO concentration was greater than other treatments, due to the $24 \mathrm{~h}$ pre-aeration, the DO concentration also decreased rapidly owing to the fast consumption of oxygen during the process of nitrification and organic matter biodegradation. When the HRT was $24 \mathrm{~h}$, the DO concentration was $\leq 1 \mathrm{mg} / \mathrm{L}$ in HSSF-CW with PA. The observed DO concentrations in the aerated HSSF-CWs with 6AA and 12AA were always greater than NA and PA with increasing HRT. Moreover, the DO concentrations were $\leq 1 \mathrm{mg} / \mathrm{L}$ when the HRT was $96 \mathrm{~h}$ in both HSSF-CWs with 6AA and 12AA. It can be summarized that AA improved the oxygen availability and prolonged the duration of aerobic conditions for all aerated HSSF-CWs. However, the change and fluctuation of DO concentrations observed in different treatments were different. Aeration after the input of influent water (refer to 6AA and 12AA) could enhance the concentrations of DO more than NA and PA. 

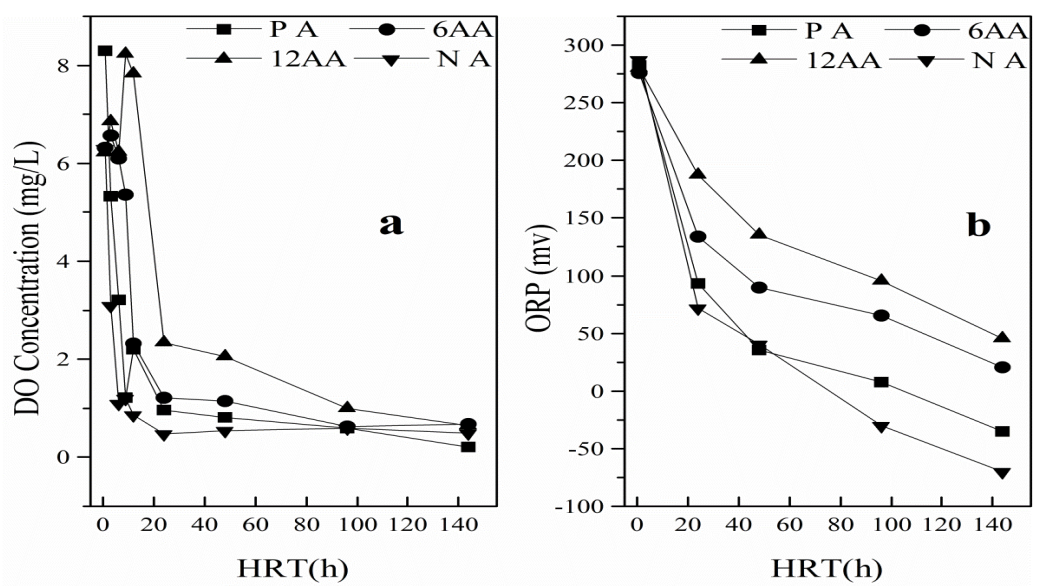

Figure 2. The changes in DO (a) and ORP (b) in HSSF-CWs with different aeration modes with increasing HRT (PA: Pre-aeration at $24 \mathrm{~h}$ before the input of influent water; 6AA: Aeration at $6 \mathrm{~h}$ after the input of influent water; 12AA: Aeration at $12 \mathrm{~h}$ after the input of influent water; NA: Non-aeration). HRT: hydraulic retention time.

ORP represents the change in the oxidation-reduction condition in CWs and previous studies have indicated that redox manipulation with AA improves the DO level $[18,23,24]$. The ORP of influent water in the feed tank of all HSSF-CWs was $281.3 \mathrm{mV}$. The ORP in all HSSF-CWs sharply decreased in the first $48 \mathrm{~h}$ due to the consumption of DO. Afterwards, the ORP slowly decreased with extension of the HRT. The ORP of NA treatment decreased to a negative value and the ORP of PA treatment was close to zero at a HRT of $96 \mathrm{~h}$ and both remained decreased afterwards. In contrast, the ORP of 6AA and 12AA remained positive because AA after the input of influent water increased the oxygen content. These above observations demonstrate that a single aeration cannot substantially and enduringly improve the redox condition of HSSF-CWs and cannot create suitable alternating aerobic and anaerobic conditions.

\subsubsection{Organic Matter Removal in HSSF-CWs with Different Aeration Modes}

The physical processes of sedimentation, filtration, interception and the microbial processes of biodegradation are major pathways for organic matter removal from CWs [8]. Organic matter removal efficiencies in the HSSF-CWs with different aeration modes are shown in Figure 3. The removal percentages of $\mathrm{COD}_{\mathrm{Cr}}$ in HSSF-CWs with $\mathrm{PA}, 6 \mathrm{AA}$ and $12 \mathrm{AA}$ were $83.9 \%, 73.2 \%$ and $77.9 \%$, respectively, while the $\mathrm{COD}_{\mathrm{Cr}}$ removal percentage in HSSF-CW with NA was $63.2 \%$. Substantial improvement in organic matter removal in aerated CWs was also observed in many previous studies $[8,12]$. This could be explained by the fact that increased DO concentrations with AA could enhance the activity of microorganisms, which would contribute to the biodegradation of organic matter. Moreover, the final $\mathrm{COD}_{\mathrm{Cr}}$ removal percentage in HSSF-CW with 12AA was lower than that in PA but higher than that in HSSF-CW with 6AA, demonstrating a substantial difference in the treatment efficiency of organic matter with different aeration modes. 


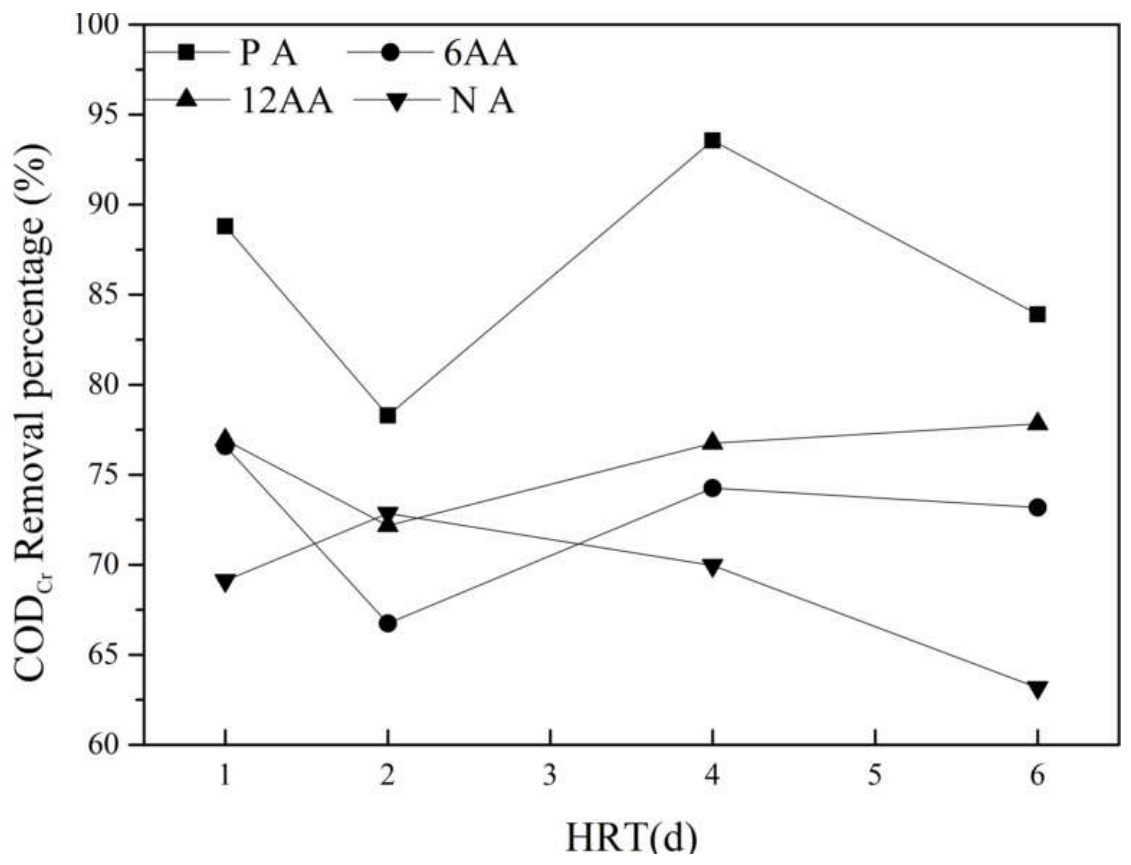

Figure 3. The $\mathrm{COD}_{\mathrm{Cr}}$ removal efficiency in HSSF-CWs with different aeration modes with increasing HRT (PA: Pre-aeration at $24 \mathrm{~h}$ before the input of influent water; 6AA: Aeration at $6 \mathrm{~h}$ after the input of influent water; 12AA: Aeration at $12 \mathrm{~h}$ after the input of influent water; NA: Non-aeration). HRT: hydraulic retention time.

\subsubsection{Nitrogen Removal in HSSF-CWs with Different Aeration Modes}

The removal percentages of $\mathrm{NH}_{4}{ }^{+}-\mathrm{N}$ and $\mathrm{NO}_{3}{ }^{-}-\mathrm{N}$ in HSSF-CWs with different aeration modes are illustrated in Figure 4. The removal percentages of $\mathrm{NH}_{4}{ }^{+}-\mathrm{N}$ in HSSF-CWs with $6 \mathrm{~A}$ and $12 \mathrm{~A}(96.2 \%$ and $92.9 \%$, respectively) were slightly higher than in HSSF-CWs with PA and NA ( $87.9 \%$ and $90.8 \%$, respectively). This observation indicates that the $\mathrm{NH}_{4}{ }^{+}-\mathrm{N}$ removal efficiency in HSSF-CWs could be enhanced by aeration after the input of influent water. In contrast to $\mathrm{NH}_{4}{ }^{+}-\mathrm{N}$ removal, the $\mathrm{NO}_{3}{ }^{-}-\mathrm{N}$ removal was found to be better in HSSF-CWs with PA (94.7\%) and NA (94.1\%) compared to HSSF-CWs with 6AA (68.1\%) and 12AA (77.1\%). This is because the excessive oxygen could lead to an aerobic environment, which inhibits the denitrification of nitrate. Additionally, the limited available organic matter might also restrain the denitrification process in HSSF-CWs $[5,9,25]$.

Although greater removal efficiencies of $\mathrm{COD}_{\mathrm{Cr}}$ and $\mathrm{NO}_{3}{ }^{-}-\mathrm{N}$ were achieved in $\mathrm{HSSF}-\mathrm{CW}$ with PA, a single pre-aeration could not stably and chronically maintain a greater removal performance with the exhaustion of oxygen. While the removal efficiencies of $\mathrm{COD}_{\mathrm{Cr}}$ and $\mathrm{NH}_{4}{ }^{+} \mathrm{N}$ were enhanced, $\mathrm{NO}_{3}{ }^{-}-\mathrm{N}$ accumulated in HSSF-CWs with aeration after the input of influent water. These above observations indicate that a single aeration (aeration before/after input) could not achieve simultaneous nitrification and denitrification. As far as is known, IA could, not only increase DO concentrations, but also reduce the operation cost of continuous aeration [26]. The influent COD/ $\mathrm{N}$ ratios can also significantly affect the removal performance of pollutants. The appropriate IA may compensate or improve the adverse effects induced by influent COD/N ratios in HSSF-CWs. Therefore, in the subsequent experiment, the combination of IA at a frequency of $12 \mathrm{~h} /$ day and different $\mathrm{COD} / \mathrm{N}$ ratios were tested to observe the removal performance of $\mathrm{COD}_{\mathrm{Cr}}$ and nitrogen in HSSF-CWs. 

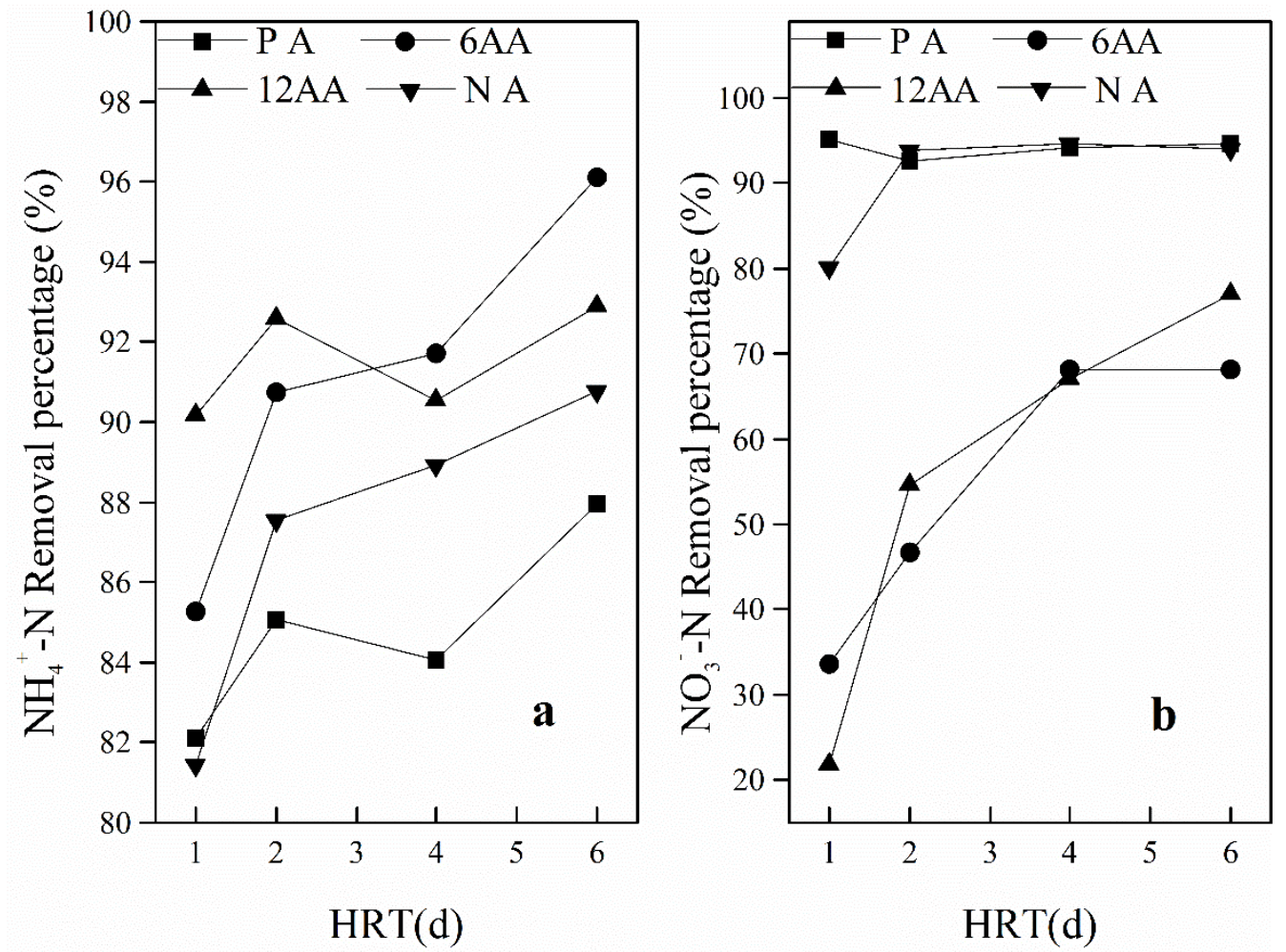

Figure 4. The removal efficiencies of $\mathrm{NH}_{4}{ }^{+}-\mathrm{N}(\mathbf{a})$ and $\mathrm{NO}_{3}{ }^{-}-\mathrm{N}(\mathbf{b})$ in $\mathrm{HSSF}-\mathrm{CWs}$ with different aeration modes. (PA: Pre-aeration at $24 \mathrm{~h}$ before the input of influent water; 6AA: Aeration at $6 \mathrm{~h}$ after the input of influent water; 12AA: Aeration at $12 \mathrm{~h}$ after the input of influent water; NA: Non-aeration)

\subsection{Impact of Influent COD/N Ratios on Organic Matter and Nitrogen Removal in HSSF-CWs with IA Mode}

\subsection{1. $\mathrm{COD}_{\mathrm{Cr}}$ Removal in HSSF-CWs under Different Influent COD/N Ratios}

The removal efficiency of $\mathrm{COD}_{\mathrm{Cr}}$ in HSSF-CWs with NA and IA under various influent COD/N ratios is shown in Figure 5. In HSSF-CW with NA, the removal percentage of $\mathrm{COD}_{\mathrm{Cr}}$ remained below $70 \%$ and relatively higher removal percentages were observed under lower influent COD/ $\mathrm{N}$ ratios (refer to $\mathrm{COD} / \mathrm{N}$ ratios at 3.0 and 3.9). Sufficient oxygen ensures the biodegradation of $\mathrm{COD}_{\mathrm{Cr}}$ when the influent $\mathrm{COD} / \mathrm{N}$ ratios are lower. With the increase in $\mathrm{COD} / \mathrm{N}$ ratios, the removal percentage of $\mathrm{COD}_{\mathrm{Cr}}$ gradually decreased. This is because the limitation of oxygen deficiency in organic matter biodegradation became more obvious in HSSF-CW with NA. The removal percentages of $\mathrm{COD}_{\mathrm{Cr}}$ in HSSF-CW with IA were $98.2 \%, 96.2 \%, 88.5 \%, 90.1 \%$ and $85.2 \%$ for influent $\mathrm{COD} / \mathrm{N}$ ratios of $3.0,3.9,8.0$, 9.3 and 11.0, respectively. A markedly better performance in organic matter degradation was observed in HSSF-CW with IA than in HSSF-CW with NA. The increasing COD/N ratios did not influence the removal efficiency of $\mathrm{COD}_{\mathrm{Cr}}$ in HSSF-CW with IA. The activity of aerobic chemoheterotrophic bacteria, that utilize oxygen as the final electron acceptor, is largely dependent on the supply of organic matter and oxygen $[12,27]$. Therefore, sufficient oxygen supply can improve the aerobic biodegradation of organic matter and enhance $\mathrm{COD}_{\mathrm{Cr}}$ removal in HSSF-CWs. 


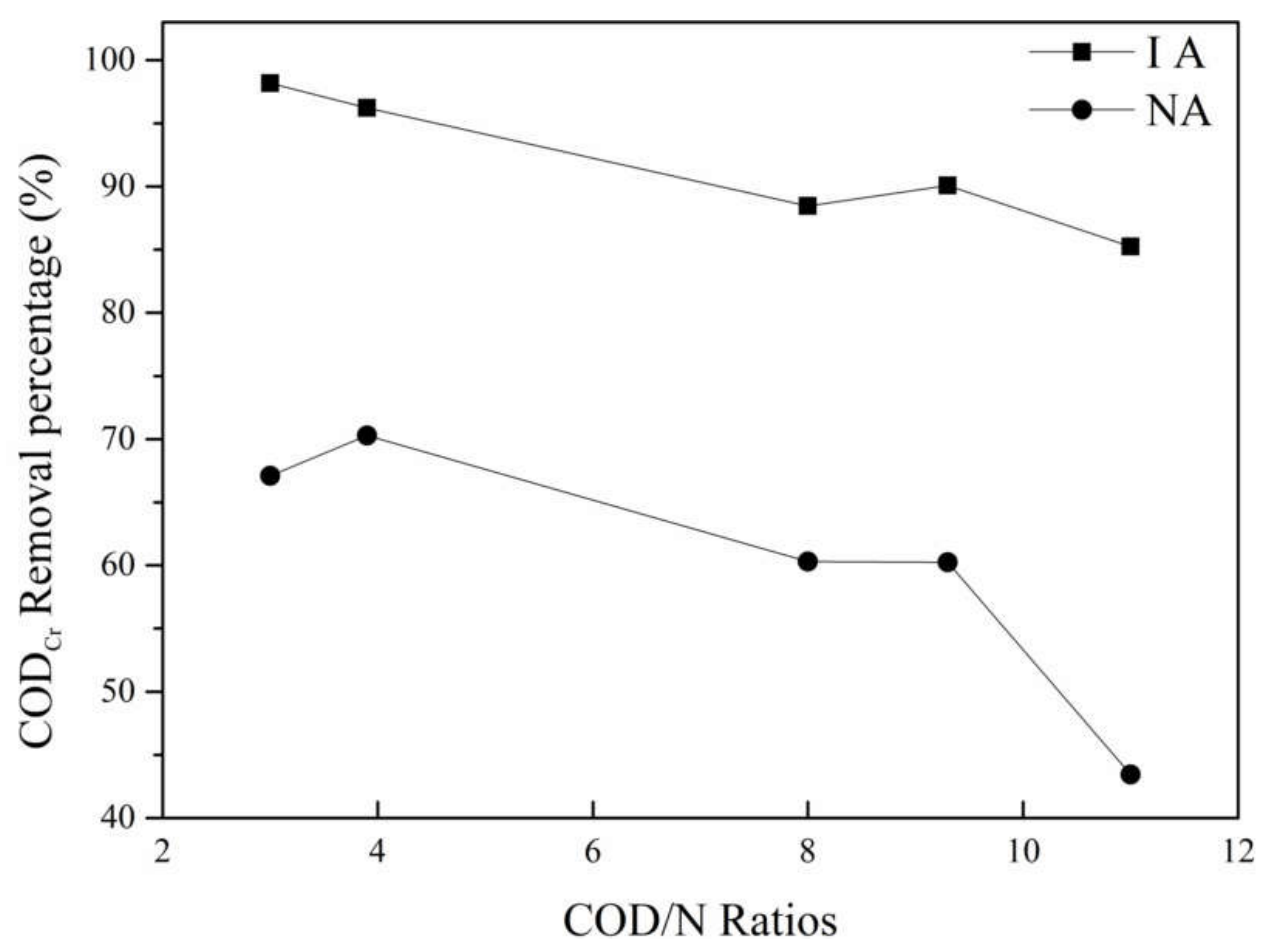

Figure 5. The removal efficiency of $\mathrm{COD}_{\mathrm{Cr}}$ in HSSF-CWs with IA and NA under different COD/N ratios. (IA: Intermittent aeration; NA: Non-aeration).

\subsection{2. $\mathrm{NH}_{4}{ }^{+}-\mathrm{N}$ and TN Removal in HSSF-CWs under Different Influent COD/N Ratios}

Nitrogen removal efficiency in most CWs was low due to their inability to provide an aerobic condition for nitrification and an anaerobic condition for denitrification simultaneously [21]. The change in $\mathrm{NH}_{4}{ }^{+}-\mathrm{N}$ and TN removal percentages with increasing COD/N ratios in HSSF-CWs with IA and NA are presented in Figure 6. As shown in Figure 6a, the removal percentages of $\mathrm{NH}_{4}{ }^{+}-\mathrm{N}$ were $92.7 \%$ and $91.1 \%$ in HSSF-CW with NA under influent COD/N ratios of 3.0 and 3.9, respectively. Subsequently, the removal percentage of $\mathrm{NH}_{4}{ }^{+}-\mathrm{N}$ decreased when the $\mathrm{COD} / \mathrm{N}$ ratio increased to 8.0 and continued to be relatively stable when the $\mathrm{COD} / \mathrm{N}$ ratios were further increased. This is because the additional organic matter had a high demand for $\mathrm{DO}$ and further hindered the nitrification. However, in HSSF-CW with IA, the removal percentage of $\mathrm{NH}_{4}{ }^{+}-\mathrm{N}$ basically remained stable with increasing COD/N ratios and was always greater than $99.2 \%$. Rising oxygen availability in HSSF-CW with IA might contribute to the aerobic chemo-autotrophic microbial process of nitrification [11]. Other previous studies also demonstrated that the activity of ammonia-oxidizing bacteria could be improved by IA [28]. This observation indicated that the aeration system could markedly improve $\mathrm{NH}_{4}{ }^{+}-\mathrm{N}$ removal even with the additional increasing carbon source.

Denitrification is an anaerobic microbial driven process and is reported to account for typically $60-95 \%$ of permanent $\mathrm{TN}$ removal in $\mathrm{CWs}$ [29]. $\mathrm{NO}_{3}{ }^{-}-\mathrm{N}$ (produced via the nitrification process) serves as an electron acceptor for respiratory electron transport and organic matter serves as an electron donor in the process of denitrification [9]. The influent $\mathrm{COD} / \mathrm{N}$ ratios could affect both the processes of nitrification and denitrification, so TN was selected as an index in this experiment for comprehensively evaluating the performance of CWs. As shown in Figure $6 \mathrm{~b}$, the removal percentages of TN were $88.2 \%$ and $87.7 \%$ in HSSF-CW with NA under influent COD/N ratios of 3.0 and 3.9, respectively. The removal percentage of $\mathrm{TN}$ reached its peak value at the influent $\mathrm{COD} / \mathrm{N}$ ratio of 8.0. It is possible that more organic matter was provided for HSSF-CW with NA, which supplied plenty of electron donors for denitrification [18]. Subsequently, the removal percentages of TN decreased from $91.5 \%$ to $82.2 \%$ in the HSSF-CW with NA when COD/N ratios increased from 8.0 to 11.0. This observation might be an outcome of organic matter degradation consuming a large amount of DO that would restrict the 
process of denitrification due to insufficient supply of $\mathrm{NO}_{3}{ }^{-}-\mathrm{N}$ as electron acceptors. In HSSF-CW with IA, the removal percentages of TN were lower with COD/N ratios of 3.0 and 3.9. The lack of organic matter supply hindered the process of denitrification and further led to the accumulation of $\mathrm{NO}_{3}{ }^{-}-\mathrm{N}$ in the presence of aeration. Wang et al. [30] also revealed that the carbon source was insufficient when $\mathrm{COD} / \mathrm{N}$ ratios were less than 4 . Subsequently, the removal percentages of TN increased to $99.5 \%$ at a COD/N ratio of 9.3 and then slightly decreased to $97.3 \%$ in HSSF-CW with IA. This observation indicated that a high efficiency of nitrification and denitrification simultaneously occurred in intermittently aerated HSSF-CWs with high COD/N ratios.
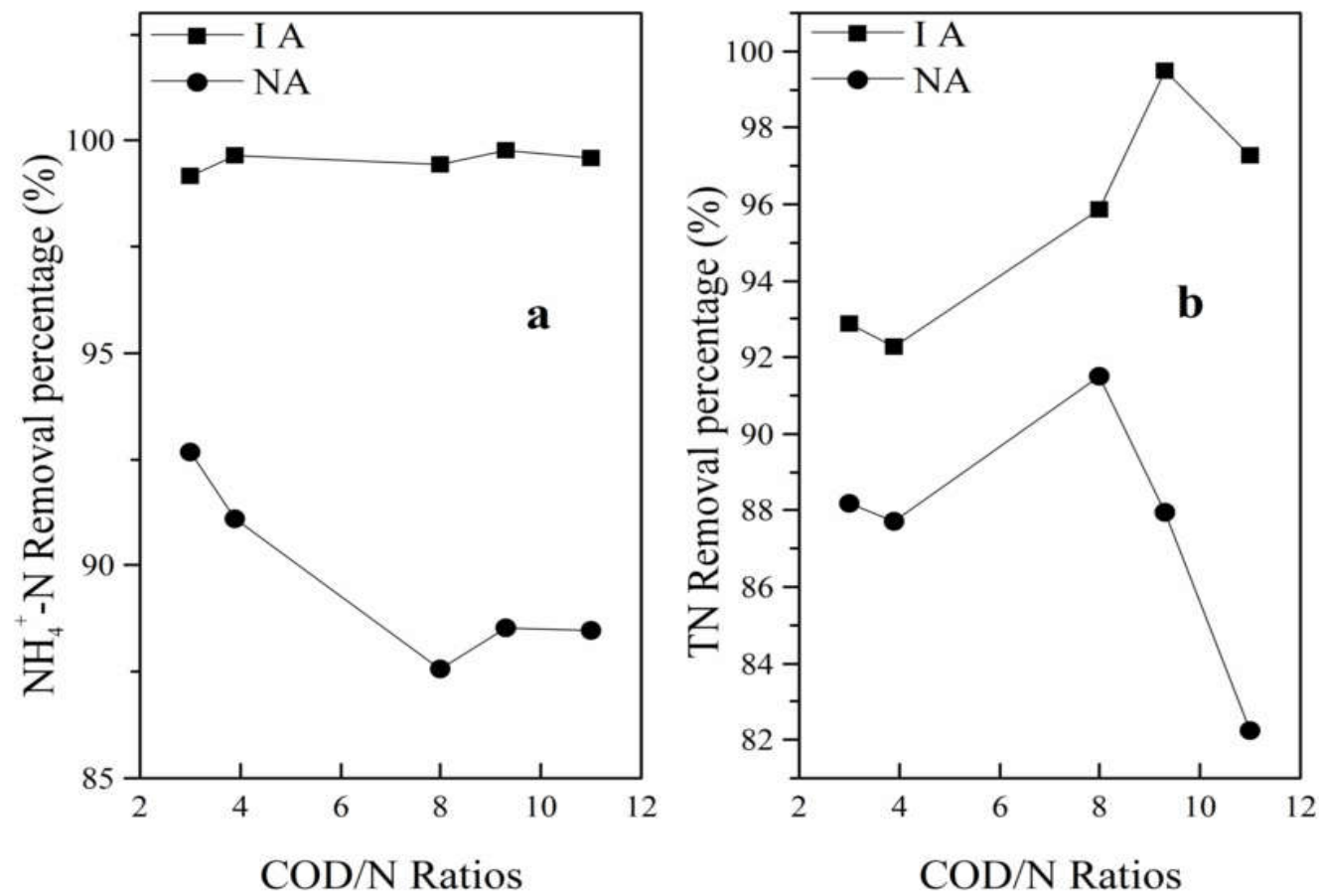

Figure 6. The removal efficiencies of $\mathrm{NH}_{4}{ }^{+}-\mathrm{N}(\mathbf{a})$ and TN (b) in HSSF-CWs with IA and NA under different $\mathrm{COD} / \mathrm{N}$ ratios (IA: Intermittent aeration; NA: Non-aeration).

It is observed that IA could achieve greater $\mathrm{NH}_{4}{ }^{+}-\mathrm{N}$ and $\mathrm{TN}$ removal percentages compared with NA. IA could facilitate the establishment of both aerobic and anaerobic environments that were suitable for nitrification and denitrification, which enhance TN removal [12,21,31]. It is noteworthy that HSSF-CW with IA could still achieve a relatively higher TN removal percentage with high COD/N ratios, which indicates that IA is suitable for the treatment of wastewater with a high concentration of organic matter.

The efficacy of CWs with AA have mostly been investigated in the laboratory or pilot scales and the pollutant removal efficiency in aerated CWs has been shown to outperform conventional CWs in many previous investigations [12-14,32]. In this study, we further tested both the influence of different aeration modes and the combined effects of IA and different COD/N ratios on the efficiency of CWs and the application of AA in CWs was also shown to be more effective than NA. Although this study was still conducted at the mesocosm scale, it could be inferred that AA might improve the performance of large scale CWs to some extent based upon results from both the current and previous studies. Future studies are recommended to evaluate and quantify the effectiveness of AA in CWs in real conditions.

\section{Conclusions}

The use of single aeration, both before and after the input of the influent water, could not simultaneously achieve relatively high removal efficiencies of $\mathrm{NH}_{4}{ }^{+}-\mathrm{N}$ and $\mathrm{NO}_{3}{ }^{-}-\mathrm{N}$ in $\mathrm{HSSF}-\mathrm{CWs}$. 
Unlike HSSF-CW with NA, an increase in COD/N ratios led to an increased removal percentage of TN and the $\mathrm{NH}_{4}{ }^{+}-\mathrm{N}$ removal percentage was maintained at a high level in HSSF-CW with IA. The greatest removal percentages of $\mathrm{NH}_{4}{ }^{+}-\mathrm{N}$ and $\mathrm{TN}$ were obtained when the COD/N ratio was 9.3. Although the removal percentage of $\mathrm{COD}_{\mathrm{Cr}}$ slightly decreased with increasing $\mathrm{COD} / \mathrm{N}$ ratios, it was always greater than $85.2 \%$ in HSSF-CW with IA. In conclusion, HSSF-CW with IA was suitable for treating wastewater with high $\mathrm{COD} / \mathrm{N}$ ratios and a $\mathrm{COD} / \mathrm{N}$ ratio of 9.3 was optimal for the removal of $\mathrm{COD}_{\mathrm{Cr}}$ and nitrogen in HSSF-CW with IA.

Author Contributions: H.Z. designed the experiment, Q.Z., X.C. and Y.X. conducted the experiments, X.C. wrote the manuscript, H.Z., B.S. and B.Y. revised the manuscript.

Funding: This research was funded by the National Key R\&D Program of China (No. 2016YFC0500404-4), the National Natural Science Foundation of China (No. 41471406) and the Youth Innovation Promotion Association of CAS (No. 2017274).

Acknowledgments: The kind assistance and advice during the whole experiment by Xiangfei Yu is appreciated.

Conflicts of Interest: The authors declare no conflict of interest.

\section{References}

1. Donde, O.O.; Xiao, B.D. Understanding wastewater treatment mechanisms: A review on detection, removal and purification efficiencies of faecal bacteria indicators across constructed wetlands. Environ. Rev. 2017, 25, 444-451. [CrossRef]

2. Chyan, J.-M.; Senoro, D.-B.; Lin, C.-J.; Chen, P.-J.; Chen, I.M. A novel biofilm carrier for pollutant removal in a constructed wetland based on waste rubber tire chips. Int. Biodeterior. Biodegrad. 2013, 85, 638-645. [CrossRef]

3. Liang, Y.X.; Zhu, H.; Banuelos, G.; Yan, B.X.; Shutes, B.; Cheng, X.W.; Chen, X. Removal of nutrients in saline wastewater using constructed wetlands: Plant species, influent loads and salinity levels as influencing factors. Chemosphere 2017, 187, 52-61. [CrossRef] [PubMed]

4. Liang, Y.X.; Zhu, H.; Banuelos, G.; Yan, B.X.; Zhou, Q.W.; Yu, X.F.; Cheng, X.W. Constructed wetlands for saline wastewater treatment: A review. Ecol. Eng. 2017, 98, 275-285. [CrossRef]

5. Wu, H.; Fan, J.; Zhang, J.; Huu Hao, N.; Guo, W.; Liang, S.; Hu, Z.; Liu, H. Strategies and techniques to enhance constructed wetland performance for sustainable wastewater treatment. Environ. Sci. Pollut. Res. 2015, 22, 14637-14650. [CrossRef] [PubMed]

6. Uggetti, E.; Hughes-Riley, T.; Morris, R.H.; Newton, M.I.; Trabi, C.L.; Hawes, P.; Puigagut, J.; Garcia, J. Intermittent aeration to improve wastewater treatment efficiency in pilot-scale constructed wetland. Sci. Total Environ. 2016, 559, 212-217. [CrossRef] [PubMed]

7. Vymazal, J. Horizontal sub-surface flow and hybrid constructed wetlands systems for wastewater treatment. Ecol. Eng. 2005, 25, 478-490. [CrossRef]

8. Wang, X.O.; Tian, Y.M.; Zhao, X.H.; Peng, S.; Wu, Q.; Yan, L.J. Effects of aeration position on organics, nitrogen and phosphorus removal in combined oxidation pond-constructed wetland systems. Bioresour. Technol. 2015, 198, 7-15. [CrossRef] [PubMed]

9. Saeed, T.; Sun, G.Z. A review on nitrogen and organics removal mechanisms in subsurface flow constructed wetlands: Dependency on environmental parameters, operating conditions and supporting media. J. Environ. Manag. 2012, 112, 429-448. [CrossRef] [PubMed]

10. Ye, F.X.; Li, Y. Enhancement of nitrogen removal in towery hybrid constructed wetland to treat domestic wastewater for small rural communities. Ecol. Eng. 2009, 35, 1043-1050. [CrossRef]

11. Liu, H.Q.; Hu, Z.; Zhang, J.; Ngo, H.H.; Guo, W.S.; Liang, S.; Fan, J.L.; Lu, S.Y.; Wu, H.M. Optimizations on supply and distribution of dissolved oxygen in constructed wetlands: A review. Bioresour. Technol. 2016, 214, 797-805. [CrossRef] [PubMed]

12. Fan, J.L.; Zhang, B.; Zhang, J.; Ngo, H.H.; Guo, W.S.; Liu, F.F.; Guo, Y.Y.; Wu, H.M. Intermittent aeration strategy to enhance organics and nitrogen removal in subsurface flow constructed wetlands. Bioresour. Technol. 2013, 141, 117-122. [CrossRef] 
13. Zapater-Pereyra, M.; Gashugi, E.; Rousseau, D.P.L.; Alam, M.R.; Bayansan, T.; Lens, P.N.L. Effect of aeration on pollutants removal, biofilm activity and protozoan abundance in conventional and hybrid horizontal subsurface-flow constructed wetlands. Environ. Technol. 2014, 35, 2086-2094. [CrossRef] [PubMed]

14. Zhang, L.Y.; Zhang, L.; Liu, Y.D.; Shen, Y.W.; Liu, H.; Xiong, Y. Effect of limited artificial aeration on constructed wetland treatment of domestic wastewater. Desalination 2010, 250, 915-920. [CrossRef]

15. Roy, D.; Hassan, K.; Boopathy, R. Effect of carbon to nitrogen (C:N) ratio on nitrogen removal from shrimp production waste water using sequencing batch reactor. J. Ind. Microbiol. Biotechnol. 2010, 37, 1105-1110. [CrossRef] [PubMed]

16. Shen, Z.Q.; Zhou, Y.X.; Liu, J.; Xiao, Y.; Cao, R.; Wu, F.P. Enhanced removal of nitrate using starch/PCL blends as solid carbon source in a constructed wetland. Bioresour. Technol. 2015, 175, 239-244. [CrossRef] [PubMed]

17. Zhao, Y.J.; Liu, B.; Zhang, W.G.; Ouyang, Y.; An, S.Q. Performance of pilot-scale vertical-flow constructed wetlands in responding to variation in influent $\mathrm{C} / \mathrm{N}$ ratios of simulated urban sewage. Bioresour. Technol. 2010, 101, 1693-1700. [CrossRef] [PubMed]

18. Zhu, H.; Yan, B.X.; Xu, Y.Y.; Guan, J.N.; Liu, S.Y. Removal of nitrogen and cod in horizontal subsurface flow constructed wetlands under different influent $\mathrm{C} / \mathrm{N}$ ratios. Ecol. Eng. 2014, 63, 58-63. [CrossRef]

19. Ding, Y.; Song, X.S.; Wang, Y.H.; Yan, D.H. Effects of dissolved oxygen and influent COD/N ratios on nitrogen removal in horizontal subsurface flow constructed wetland. Ecol. Eng. 2012, 46, 107-111. [CrossRef]

20. Liu, L.; Zhao, X.H.; Zhao, N.; Shen, Z.; Wang, M.; Guo, Y.Z.; Xu, Y.B. Effect of aeration modes and influent $\mathrm{COD} / \mathrm{N}$ ratios on the nitrogen removal performance of vertical flow constructed wetland. Ecol. Eng. 2013, 57, 10-16. [CrossRef]

21. Fan, J.L.; Wang, W.G.; Zhang, B.; Guo, Y.Y.; Ngo, H.H.; Guo, W.S.; Zhang, J.; Wu, H.M. Nitrogen removal in intermittently aerated vertical flow constructed wetlands: Impact of influent cod $/ \mathrm{n}$ ratios. Bioresour. Technol. 2013, 143, 461-466. [CrossRef] [PubMed]

22. Water Quality-Determination of Chemical Oxygen Demand-Dichromate Method; GB11914-89; Environmental Protection Agency (EPA) of China: Beijing, China, 1989.

23. Zhang, X.; Inoue, T.; Kato, K.; Harada, J.; Izumoto, H.; Wu, D.; Sakuragi, H.; Ietsugu, H.; Sugawara, Y. Performance of hybrid subsurface constructed wetland system for piggery wastewater treatment. Water Sci. Technol. 2016, 73, 13-20. [CrossRef] [PubMed]

24. Zhong, F.; Wu, J.; Dai, Y.R.; Yang, L.H.; Zhang, Z.H.; Cheng, S.P.; Zhang, Q. Bacterial community analysis by PCR-DGGE and 454-pyrosequencing of horizontal subsurface flow constructed wetlands with front aeration. Appl. Microbiol. Biotechnol. 2015, 99, 1499-1512. [CrossRef] [PubMed]

25. Dong, H.Y.; Qiang, Z.M.; Li, T.G.; Jin, H.; Chen, W.D. Effect of artificial aeration on the performance of vertical-flow constructed wetland treating heavily polluted river water. J. Environ. Sci. 2012, 24, 596-601. [CrossRef]

26. Ilyas, H.; Masih, I. The performance of the intensified constructed wetlands for organic matter and nitrogen removal: A review. J. Environ. Manag. 2017, 198, 372-383. [CrossRef] [PubMed]

27. Garcia, J.; Rousseau, D.P.L.; Morato, J.; Lesage, E.; Matamoros, V.; Bayona, J.M. Contaminant removal processes in subsurface-flow constructed wetlands: A review. Crit. Rev. Env. Sci. Technol. 2010, 40, 561-661. [CrossRef]

28. Wu, H.M.; Fan, J.L.; Zhang, J.; Ngo, H.H.; Guo, W.S.; Hu, Z.; Liang, S. Decentralized domestic wastewater treatment using intermittently aerated vertical flow constructed wetlands: Impact of influent strengths. Bioresour. Technol. 2015, 176, 163-168. [CrossRef] [PubMed]

29. Lee, C.G.; Fletcher, T.D.; Sun, G.Z. Nitrogen removal in constructed wetland systems. Eng. Life Sci. 2009, 9, 11-22. [CrossRef]

30. Wang, W.; Ding, Y.; Ullman, J.L.; Ambrose, R.F.; Wang, Y.H.; Song, X.S.; Zhao, Z.M. Nitrogen removal performance in planted and unplanted horizontal subsurface flow constructed wetlands treating different influent COD/N ratios. Environ. Sci. Pollut. Res. Int. 2016, 23, 9012-9018. [CrossRef] [PubMed] 
31. Foladori, P.; Ruaben, J.; Ortigara, A.R.C. Recirculation or artificial aeration in vertical flow constructed wetlands: A comparative study for treating high load wastewater. Bioresour. Technol. 2013, 149, $398-405$. [CrossRef] [PubMed]

32. Ilyas, H.; Masih, I. Intensification of constructed wetlands for land area reduction: A review. Environ. Sci. Pollut. Res. 2017, 24, 12081-12091. [CrossRef] [PubMed] 